\title{
Winning the Peace Locally: UN Peacekeeping and Local Conflict
}

\author{
Andrea Ruggeri, andrea.ruggeri@politics.ox.ac.uk, University of Oxford \\ Han Dorussen, hdorus@essex.ac.uk, University of Essex \\ Theodora-Ismene Gizelis, tig@essex.ac.uk, University of Essex
}

\begin{abstract}
It remains contested whether peacekeeping works. The impact of peacekeepers' actions at the local (or subnational) level for overall mission success has lately received critical attention. Local peacekeeping is expected to matter because it re-assures local actors, deters resumption of armed hostilities, coerces parties to halt fighting, and makes commitment to agreements credible. Thus peacekeepers affect the relations between central and local elites and avoid the emergence of local power vacuums and areas of lawlessness. This study uses new subnational data on the deployment of United Nations peacekeepers. It uses matching and recursive bivariate probit models with exogenous variables for temporal and spatial variation to deal with possible non-random assignment of the treatment. It is demonstrated that conflict episodes last shorter when peacekeepers are deployed to conflict-prone locations inside a country, even with comparatively modest deployment. The effect of peacekeeping on the onset of local conflict is, however, less clear-cut.
\end{abstract}

\section{Word count: $\mathbf{7 , 8 8 2}$}

Authors1 2013: Ruggeri, Andrea ,Theodora-Ismene Gizelis and Han Dorussen.2013.

"Managing Mistrust: an Analysis of Cooperation with UN Peacekeeping in Africa." Journal of Conflict Resolution 57 (3): 387-409.

Authors2 2013: Dorussen, Han and Theodora-Ismene Gizelis. 2013. “Into the Lion's Den:

The Reception of UN Peacekeeping Efforts.” Journal of Peace Research 50(6): 691706.

Authors3 2015: Ruggeri, Andrea, Han Dorussen and Theodora-Ismene Gizelis. 2015. "Every

Day on the Frontline? Sub-National Deployment of UN Peacekeeping”, manuscript.

* We are grateful for funding from the Folke Bernadotte Academy, Sweden and ESRC grant RES-062-23-0259 as well as comments from participants at workshops and conference presentations, in particular Vincenzo Bove, Tobias Bohmelt, Michael Gilligan, Lisa Hultman and Julian Wucherpfennig. 


\title{
Winning the Peace Locally: UN Peacekeeping and Local Conflict
}

\begin{abstract}
It remains contested whether peacekeeping works. The impact of peacekeepers' actions at the local (or subnational) level for overall mission success has lately received critical attention. Local peacekeeping is expected to matter because it re-assures local actors, deters resumption of armed hostilities, coerces parties to halt fighting, and makes commitment to agreements credible. Thus peacekeepers affect the relations between central and local elites and avoid the emergence of local power vacuums and areas of lawlessness. This study uses new subnational data on the deployment of United Nations peacekeepers. It uses matching and recursive bivariate probit models with exogenous variables for temporal and spatial variation to deal with possible non-random assignment of the treatment. It is demonstrated that conflict episodes last shorter when peacekeepers are deployed to conflict-prone locations inside a country, even with comparatively modest deployment. The effect of peacekeeping on the onset of local conflict is, however, less clear-cut.
\end{abstract}

Word count: 7,882 
Peacekeeping has become one of the main methods of the international community to resolve civil wars. Yet it remains disputed whether peacekeeping operations (PKO) actually reduce conflict, and many question whether peacekeepers improve the situation on the ground. ${ }^{1} \mathrm{~A}$ further difficulty is to integrate mixed findings of macro- and micro-level studies. A significant body of research finds that UN peacekeepers select so-called 'hard cases,' or civil wars that are difficult to settle; ${ }^{2}$ but deployment to a country with a civil war need not imply that peacekeepers are operating in actual conflict 'hot-spots' ${ }^{3}$

Recent quantitative studies on peacekeeping have shifted their focus from the mission as a whole to specific activities and policies as well as the precise geographical area of operations. Authors $1^{4}$ find that UN missions reduce mistrust between belligerents conditional on the size of the mission and the balance of power between rebels and government forces. Further, Hultman, Kathman and Shannon ${ }^{5}$ provide strong evidence that UN missions tend to save civilian lives. Costalli ${ }^{6}$ studies subnational variation in the presence of UN peacekeepers in Bosnia and highlights that the UN is active where there has been high level of violence against civilians, however, without necessarily diminishing the level of violence. Fjelde, Hultman and Nilsson demonstrate that the more peacekeeping forces are locally deployed, the less likely that the belligerents will carry out attacks against civilians. ${ }^{7}$ Our analysis

\footnotetext{
${ }^{1}$ Autesserre 2010; Pouligny 2006.

${ }^{2}$ Sambanis and Doyle 2007; Fortna 2008; Gilligan and Sergenti 2008; Hegre et al. 2011.

${ }^{3}$ Authors3 2015; Braithwaite 2005.

${ }^{4}$ Authors 12013.

${ }^{5}$ Hultman et al. 2013; 2014.

${ }^{6}$ Costalli 2013.

${ }^{7}$ Fjelde et al. 2015. 
considers the impact of peacekeeping on the onset and duration of local armed conflict, defined as the organized and armed use of violence between governmental and rebel forces at a particular locality. ${ }^{8}$

For a number of reasons, it is reasonable to expect peacekeeping at the local level to matter. Although elites generally negotiate peace agreements at the national level, peace is often 'won locally'. Peace agreements and ceasefires provide opportunities for government and rebel authorities to strengthen their hand, and peacekeepers assist the peace process by providing transparency about the actions of government and rebel leaders. Peacekeepers can also compensate for lack of elite control over areas where the conflict has left a power vacuum. Although monitoring depends less on deployment size, more peacekeepers are needed to effectively patrol and control areas. Alternatively, peacekeepers can be called upon to address local conflict dynamics, highlighting local grievances, interests and sources of power often caught up in the broader conflict. ${ }^{9}$ Peacekeeping matters by separating local from national issues and reassuring that national agreements provide sufficient local gains. Where a modest local presence may enable peacekeepers to mediate, a substantial presence of peacekeepers is needed to deal with spoilers and breakaway factions relying on their local powerbase to pursue local agendas. By reducing local conflict, peacekeeping also affects national-level stability. Effective peacekeeping halts the escalation and spread of conflict, it maintains trust in the peace process, and avoids zones of lawlessness. All these elements are essential to support nationwide peace agreements.

\footnotetext{
${ }^{8}$ The research design section elaborates the operationalization. Our contribution is within the study of civil wars and conflict dynamics between belligerents. We do not aim, in this article, to study one-side violence or violence against civilians.

${ }^{9}$ Kalyvas 2006.
} 
Our empirical analysis uses new spatially disaggregated UN peacekeeper deployment data for eight African countries to examine the effect of peacekeeping on the onset and duration of conflict locally. Authors $3^{10}$ find that UN peacekeepers tend to be deployed to conflict areas but with a significant time delay, raising the question whether PKOs actually contain and deter local conflict. Therefore, we use matching techniques as well as recursive bivariate probit regression to take into account possible non-random assignment of the subnational deployment of peacekeepers. We find that UN peacekeeping reduces the duration of conflict locally. The presence of peacekeepers already matters, but if more peacekeepers are deployed to a particular locality, they shorten conflict episodes more effectively. The evidence is inconclusive for the ability of peacekeepers to deter the onset of local conflict.

The next section elaborates the arguments on the local dynamics of conflict and peacekeeping and argues specifically why the local deployment of peacekeepers matters for the onset and duration of conflict. Section three outlines the research design, while section four presents the main empirical findings. Section five concludes.

\section{How Local Peacekeeping Matters}

Peacekeepers may enhance the prospects for peace locally in different ways. Recently socalled robust peacekeeping has received most attention, but apart from enforcement, peacekeepers can also strengthen peace agreements via credible commitment, deterrence, and re-assurance. Notably, all these mechanisms are ultimately implemented subnationally. The four distinct mechanisms specify how the presence of peacekeepers locally and their deployment size relates to conflict onset and duration.

${ }^{10}$ Authors 32015 . 
MONITORING AND CREDIBLE COMMITMENT Rebels and government regularly continue to compete for territorial control and the 'post'-conflict loyalty of the local population, and opportunism remains a salient conflict mechanism. Even if their relative military strength is known, government and rebels may remain uncertain about their support among the population. The division of territorial control that rebels and government established on the battlefield no longer applies, and the end of fighting may encourage locals to express their true allegiance. The government also regains access to areas that were out of bounds during the war.

Via monitoring and reporting on activities 'on the ground', peacekeepers can demonstrate the commitment of the government and rebels to a peace agreement. The presence of peacekeepers in specific localities matters because it commits leaders to act locally in line with centrally agreed principles. Information about the implementation of the peace agreement is crucial for its success, because the peace process provides opportunities for the former belligerents to strengthen their positions. Referring to (alleged) behavior of rebels during elections in Namibia, Lindley noted that "UNTAG built credibility by being honest and not glossing over obvious problems. For example, on September 21, 1989, UNTAG reported on the radio that political intimidation was rife and increasing in the North as the political campaign got more serious. Intimidations in the North subsided and did not threaten the elections". ${ }^{11}$ Peacekeepers also act as a third-party guarantor of the original agreement. DDR and SSR are common elements of peace agreements that directly affect the (military) balance of power. These changes may tempt parties to challenge the terms of the original settlement; for example, in the aftermath of the Lomé Peace Accord (1999) between the government of Sierra Leone and the Revolutionary United Front's (RUF), robust

${ }^{11}$ Lindley 2007: 148. 
peacekeeping resolved the commitment problems that emerged between the different fighting parties. $^{12}$

Generally, however, monitoring and providing accurate information does not require a deployment in large numbers: the mere presence of UN personnel already creates an information flow between the parties allowing them to update their bargaining positions in a non-violent fashion. ${ }^{13}$ The role of peacekeepers to enhance the commitment of elites to the peace process supports the following hypothesis for the onset of armed conflict locally:

H1: The onset of armed conflict is less likely in areas where peacekeepers are deployed.

PATROLLing AND DETERRENCE Government and rebel leaders commonly have only limited control over the actions of their 'followers' who may not feel bound by the terms of the agreement. ${ }^{14}$ Internal clashes within the rebel groups occasionally lead to changes in their leadership as, for example, the case of M23 in the DRC illustrates. Subsequently, the new leadership can decide to renege on the original peace agreement. Prunier poignantly describes the situation for the eastern Congo: "because there had never been a unified command capable of carrying out a coherent centralized strategy, bringing under control the myriad feuding units was akin to trying to harness a bunch of wild horses to a cart."15 So-called spoilers have little reason to accept the peace agreement and may even feel threatened by the re-establishment of central authority and demands for transitional justice. ${ }^{16}$

\footnotetext{
${ }^{12}$ Olonisakin 2008.

${ }^{13}$ Powell 2004.

${ }^{14}$ Mitchell 2009.

${ }^{15}$ Prunier 2008: 337.

${ }^{16}$ Kydd and Walter 2002; Nilsson 2008.
} 
Peacekeepers deter the onset of local conflict when their presence and actions discourage parties to use force. The relation between the government (and rebel) elites and spoiler or renegade factions is often complex. During the conflict, elites tend to encourage, mobilize and arm grassroots groups with strong local identity and powerbase to fight alongside 'regular' troops. Autesserre ${ }^{17}$ details how local social, political and economic agendas lead to distinct patterns of violence after the end of civil war. During civil war different factions coalesce along a main cleavage giving national elites more prominence, while the end of the fighting reduces elite control and encourages the splintering of local (armed) groups. In such situations, peacekeepers can deter the resumption of fighting if patrolling demonstrates effective control over an area.

Deterrence differs from commitment: peacekeepers commit if their presence ensures that leaders who have retained control over local actors are not tempted to revise the terms of the peace agreement. In contrast, peacekeepers deter by compensating for the lack of control by leaders (government and rebels alike) over local parties. Deterrence applies to situations where local factions operate more independently from national politics, are heavier armed and better organized. It is likely to require robust peacekeeping with a sufficient number of troops; especially because local 'grassroots' groups are not only armed but also often rely on a reputation established during the civil war for their social status. The following hypothesis is testable at the subnational level:

H2: The larger the presence of UN forces in areas prone to conflict, the lower is the probability of conflict onset.

${ }^{17}$ Autesserre 2010: 126-173. 
local conflict dynamics, "in particular, disputes that regional and national actors manipulated or that could serve as triggers for a renewal of the broader conflict". ${ }^{18}$ The failure to address local grievances and demands for justice undermines support for the peace process, ${ }^{19}$ as these grievances and agendas can sustain generally low-level conflict. Personal grievances and prospects for personal gains often motivate support for either rebels or government, where villagers try to use the civil war to settle disputes that are basically local. ${ }^{20}$ Following civil war, refugees and internally displaced people may decide to return home and reclaim 'their' land and other properties left behind. ${ }^{21}$ When a population has forged ties with different factions, civil war weakens the capacity and legitimacy of local institutions to deal with disputes. $^{22}$ The Capstone Doctrine ${ }^{23}$ acknowledges the importance of local actors and conflict dynamics in sustainable peace building, making the interaction with and involvement of local actors more important.

Peacekeepers can separate local from national grievance by recognizing local tensions, providing early warning, and increasing awareness that conflicts often persist in parts of the country. Accurate information again plays an important role in dealing with ongoing conflict at the local level; for example, in dealing with violent protests in response to the arrests of Kosovo Liberation Army heroes by UNMIK in 2002, "UNMIK got the top

\footnotetext{
${ }^{18}$ Autesserre 2010: 194.

${ }^{19}$ Rotberg 2002; Pouligny 2006.

${ }^{20}$ Kalyvas 2006.

${ }^{21}$ Autesserre 2010: 173-174.

${ }^{22}$ Pons-Vignon and Lecomte 2004.

${ }^{23}$ UN DPKO 2008
} 
policy people on the TV that night and showed that those arrested had tortured Albanians (....). The protests 'stopped on a dime'.,24

Wall and Druckman ${ }^{25}$ report that peacekeepers regularly mediate in local conflicts using a broad set of techniques, including gathering information, meeting separately with disputants and, if necessary, asking third parties to assist. When peacekeepers mediate local disputes or create conditions for other actors (such as NGOs) to provide governance, these tasks relate closely to policing local communities. To summarize, peacekeepers can effectively mediate in on-going, often low-level, local disputes, where interventions frequently rely on civilian rather than military expertise. However, mediation only rarely requires robust peacekeeping and relatively small deployments generally suffice.

H3: Armed conflict is less likely to continue in areas where peacekeepers are deployed.

ENFORCEMENT In the aftermath of civil war, neither the government nor the rebels tend to have full control over parts of the country, leaving a power vacuum for external, transnational, actors. Buhaug, referring to Boulding's ${ }^{26}$ Loss of Strength Gradient, argues that governments often have only limited control at the periphery, making these areas particularly vulnerable. ${ }^{27}$ Civil war undermines central control, which reveals the weakness of the government, increases the availability of arms and encourages meddling from neighboring countries. Peace agreements may also limit the control of rebel groups - either because of demobilization or by incorporating them into the central authority of a country-without

\footnotetext{
${ }^{24}$ Lindley 2007: 205-206.

${ }^{25}$ Wall and Druckman 2003: 702.

${ }^{26}$ Boulding 1962.

${ }^{27}$ Buhaug 2010.
} 
necessarily increasing the control of the central government. The 'post'-conflict situation in the Congo illustrates many of these features; for Rwandese and Ugandan armies as well as civilian militias war had "become a way of life" and was taken "to the village level." ${ }^{28}$ In such cases, peacekeepers have to substitute for lack of effective elite control and to fill the power vacuum that prevails in the aftermath of armed conflict. Border areas have received the most attention, and are seen as particularly relevant when there is the risk of contagion from conflict in neighboring countries. Transferring of resources and weapons and possibly direct interference by foreigners create risks for spillover. Peacekeepers can either directly halt incursions or stop the use of violence by marauding gangs.

During and after civil wars, criminal activities and local conflict dynamics often become entwined, blurring the distinction between warfare and criminal gang activities. ${ }^{29}$ Conflict destroys opportunities for peaceful economic activities and rewards violent behavior, often encouraging 'independent' local militias and rebel groups to target displaced persons. ${ }^{30}$ Often these groups consist of criminal gangs fuelled by drugs and alcohol rather than political agendas, such as the 'armies' of Prince Johnson and General Butt Naked in Liberia and Arkan in the former Yugoslav wars. ${ }^{31}$ Peace enforcement imposes costs on local belligerents outweighing their expected gains from continuing to fight and can thus shorten local conflict. Whereas deterrence prevents the outbreak of conflict, intervention aims to halt on-going conflict through the application of force; hence follows the empirical implication summarized in Hypothesis 4:

\footnotetext{
${ }^{28}$ Prunier 2008: 337.

${ }^{29}$ Mueller 2003.

${ }^{30}$ Melander 2009.

${ }^{31}$ Mueller 2003.
} 
H4: The larger the presence of UN forces in conflict areas, the lower is the probability that conflict continues.

\section{Research Design}

We use spatially disaggregated information on the location of conflict as well as the deployment of peacekeeping forces. Our sample includes all major UN missions in subSaharan Africa from 1989 until 2006: Angola, Burundi, Central African Republic, Democratic Republic of Congo, Ivory Coast, Liberia, Sierra Leone, and Sudan. The geographic unit of analysis is a grid cell of $0.5 \times 0.5$ decimal degrees ${ }^{32}$ with year as the temporal unit resulting in a total of 14,146 observations for the unmatched sample. ${ }^{33}$

Figure 1 illustrates the operationalization of the grid structures, as well as the location of UN deployment for the cases of Liberia, Sierra Leone and Ivory Coast. The colored grids depict areas where UN deployed, where a darker color indicates more peacekeepers in a particular grid. Deployment data are estimates based on UN information. ${ }^{34}$ Peacekeeper $(P K O)$ presence is a dummy variable indicating whether a permanent UN peacekeeper base exists in a grid during the year. The deployment maps are included regularly in the reports of the UN Secretary General and provide additional information on the nature of the contingents deployed and the nationality of the peacekeepers deployed at the bases. Accordingly, PKO size estimates the number of peacekeepers deployed in a certain area in any given year.

\footnotetext{
${ }^{32} 0.5$ decimal degrees at the equator is roughly $50 \mathrm{~km}$; see Tollefsen et al. 2012 also in relation to the discussion one the "unit modifiable" problem.

${ }^{33}$ The findings presented below are robust for the stable unit treatment value assumption (SUTVA).

${ }^{34}$ Authors3 2015. 
The Conflict Site Dataset (CSD) is used to identify the location of violent conflict. CSD is an extension to the UCDP/PRIO Armed Conflicts Dataset and provides coordinates for the conflict zones in given countries. ${ }^{35}$ The CSD data identify a conflict centroid and create a buffer around the area. It is important to note that the location of the conflict, both the centroid and buffer, changes over time.

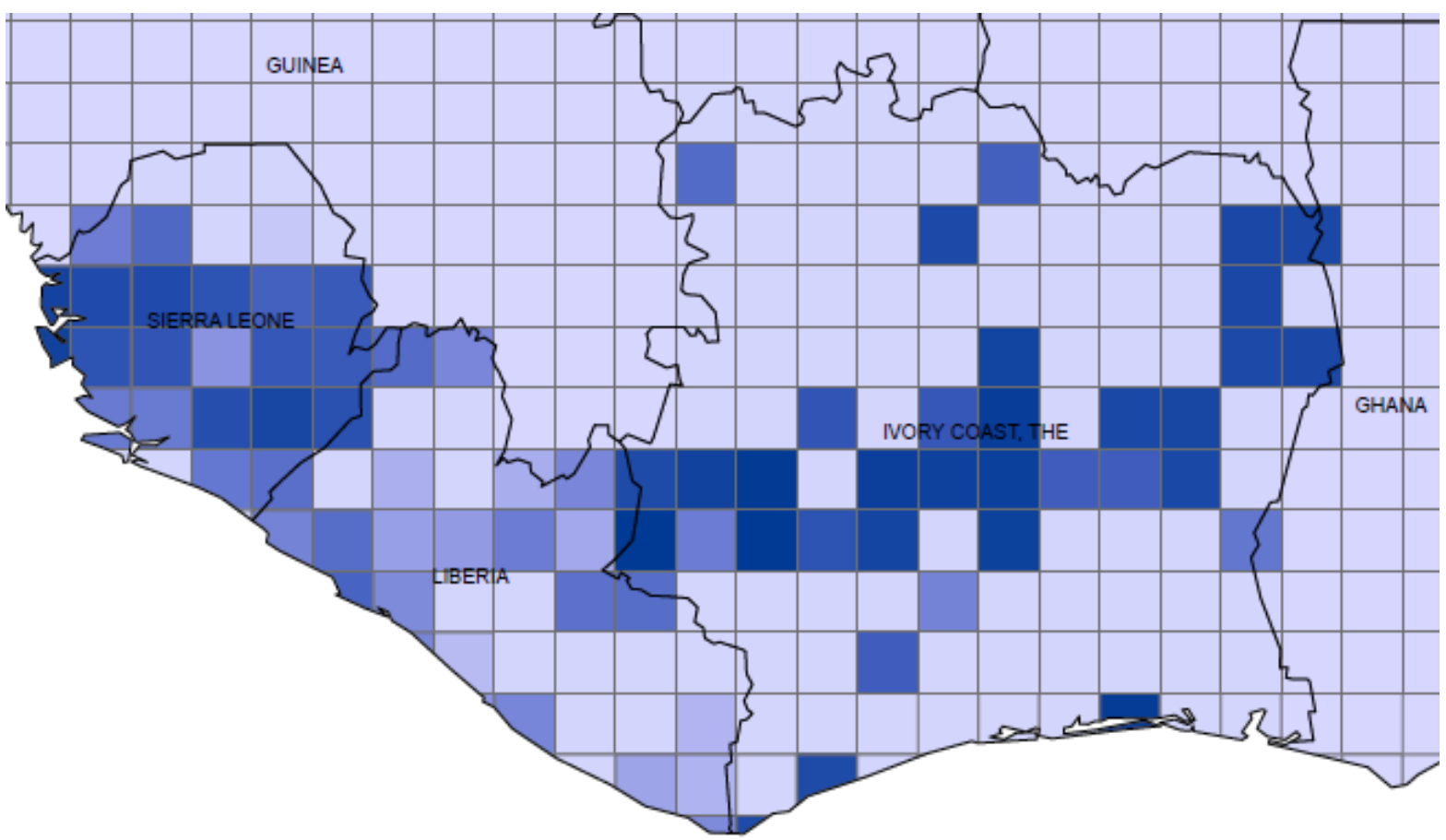

Note: this is an over-time grid average. Darker grids correspond to stronger UN deployment

Figure 1: The Distribution of the Number of Peacekeepers - Sierra Leone, Liberia and Ivory Coast

Terrain and geographical distances are likely to influence the effectiveness of peacekeeping troops depending on the quality of existing infrastructure. Reliable infrastructure is important for the UN to support its operations, and to some extent lack of infrastructure explains delays in responding to conflict in outlying areas. Accordingly, the

\footnotetext{
${ }^{35}$ Dittrich Hallberg 2012.
} 
models contain a series of factors, such as average travelling time, border distance, and capital distance that measure the feasibility and cost of deploying to a certain area.

Average Travelling Time gives the estimated cell-average travel time (in minutes) by land transportation from the cell to the nearest major city with more than 50,000 inhabitants. The values are extracted from a global high-resolution raster map of accessibility. ${ }^{36}$ Border Distance is the geographical distance of the center of each cell (centroid) from the international borders in kilometers and Capital Distance the distance in kilometers from the capital $^{37}$. The variable Average Mountains measures the roughness of the terrain. The variable is constructed as the logged percentage per grid of the land that is covered by mountains using data from the United Nations Environmental Program (UNEP) and the Food and Agricultural Organization (FAO). Since the size of the country and, therefore, the number of grids vary considerably, we also control for the total number of grids per country. Finally, we add further grid characteristics that could affect the likelihood of conflict such as Infant Mortality Rate, a proxy for social and economic development, and Population. ${ }^{38}$

Two methodological concerns have determined the choice of estimation technique. Firstly, the hypotheses relate to the probability of conflict onset and duration. Onset of conflict implies that there was no violent conflict in the previous period, while duration of conflict implies the presence of conflict in the previous period. First-order Markov models provide appropriate estimators to compare the effects of covariates on the probability of onset with their effects on the duration of subnational conflict. Markov transition models can be expressed as a system of two equations using a logit link:

\footnotetext{
${ }^{36}$ Nelson 2008.

${ }^{37}$ Tollefsen et al. 2012.

${ }^{38}$ Tollefsen et al. 2012.
} 


$$
\begin{gathered}
P\left(Y_{i, t}=1 \mid Y_{i, t-1}=0\right)=\operatorname{Logit}\left(X_{i, t} \beta\right) \\
P\left(Y_{i, t}=1 \mid Y_{i, t-1}=1\right)=\operatorname{Logit}\left(X_{i, t} \alpha\right)
\end{gathered}
$$

Beck, Katz and Tucker ${ }^{39}$ demonstrate that binary time-series cross-section (BTSCS) analysis with temporal dependency is essentially a grouped duration model. Markov transition models allow the inclusion of covariates that affect the probability of onset, the probability of duration, or both probabilities. The likelihood of transitions between states or duration at the same state is estimated by conditioning on the outcome of the previous period. Conflict onset is analyzed by constraining the sample to cases without conflict in the previous period. To study the duration of conflict, the sample is constrained to cases with conflict in the previous period. In order to take into account further temporal dependence we include a cubic polynomial temporal approximation ${ }^{40}$ for time at peace (when estimating conflict onset) or for time at conflict (when estimating conflict duration).

A second methodological concern is possible non-random assignment of PKO deployment in our units under analysis. Peacekeepers might avoid areas with high risk of conflict, rendering any correlation between peacekeeping and the absence of conflict potentially spurious. Previous research has shown that peacekeepers tend to go to areas with conflict in the recent past, but the deployment decisions are often conditional on logistical constrains such as travelling distance from urban areas. ${ }^{41}$

Given the possible selection bias in deployment, we have opted for two estimation strategies to secure robust inferences. Firstly, matching techniques ${ }^{42}$ are used in preparing the

\footnotetext{
${ }^{39}$ Beck et al. 1998.

${ }^{40}$ Carter and Signorino 2010.

${ }^{41}$ Authors3 2015.

${ }^{42}$ Iacus, King and Porro 2011.
} 
data before further analysis using logit regression; alternatively we use recursive bivariate probit. ${ }^{43}$ The number of observations of the pre-matched units is 14,146 without PKO and 736 with PKO. After matching, the number of observations drops down to 1,005 units without PKO and 622 with PKO.

We use the Coarsened Exact Matching (CEM) introduced by Iacus, King and Porro. ${ }^{44}$ Contrary to other matching methods, CEM guarantees that the imbalance between the treatment and control groups in the specific sample is reduced. In essence, CEM coarsens the independent variables and recodes them, so that very close values are grouped together. ${ }^{45}$ The Exact Matching algorithm is subsequently used to detect the matches within the coarsened data and to put aside the unmatched cases. Finally, the coarsened values are abandoned and the original values of the matched data are maintained for the analysis of the causal effect. We include observables in our matching procedure highlighted in previous research on peacekeepers' subnational deployment such as Average Travelling Time, Capital Distance, and Border Distance. ${ }^{46}$ Moreover, we match for grid characteristics identified in the disaggregate literature of civil war: Infant Mortality Rate, Population, Average Mountains, and Average Rain Precipitation. ${ }^{47}$ The matching variables aim to satisfy the "unconfoundedness" assumption, which maintains that we have enough controls so that,

${ }^{43}$ Greene 2003: 715-716.

${ }^{44}$ Iacus, King and Porro 2011.

${ }^{45}$ Findings are robust for models with alternative matching techniques; see Tables $\mathrm{C}$ in appendix.

${ }^{46}$ Authors3 2015.

${ }^{47}$ Buhaug 2010. 
conditional on those controls, treatment assignment is essentially random ${ }^{48}$ and these covariates are known to be unaffected by the treatment. ${ }^{49}$

Table 1 reports the multivariate $\mathrm{L} 1$ distance before and after the matching. The L1 distance is a synthetic indicator that summarizes to what extent the two subsamples-regions that have experienced peacekeeping and regions that have not-differ in their characteristics. The higher the value, the more different the characteristics of the two samples are and the higher the need for matching. The value of L1 before matching was 0.95 , indicating the possibility of sample selection. CEM substantially reduces L1 (from 0.95 to 0.17 ), providing a much more balanced sample. The same table also reports the individual variable L1 distances for the observables, indicating that all values decreased dramatically (see Figure 2). For example, after the matching the observations are much more closely matched on key geographical variables (Average Travelling Time) as well as on socio/economic factors (here, Population.$^{50}$

\footnotetext{
${ }^{48}$ Wooldridge 2009.

${ }^{49}$ Imbenes 2014: 5.

${ }^{50}$ Since there is variation in the countries' representation within our sample before and after matching, we re-run the models using country-wise sample deletion. Our findings remain robust when applying the jackknife approach to the matched sample. Results available upon request. 
Table 1: Similarity of Matched and Unmatched Samples on Key Characteristics. L1 Distances.

\begin{tabular}{lcc}
\hline & $\begin{array}{c}\text { L1 Distance } \\
\text { Before Matching }\end{array}$ & $\begin{array}{c}\text { L1 Distance } \\
\text { After Matching }\end{array}$ \\
\hline Average Travelling Time & .46 & .09 \\
Population & .42 & .02 \\
Average Distance Capital & .40 & .03 \\
Infant Mortality Rate & .38 & .00 \\
Average Precipitation & .31 & .01 \\
Average Distance Border & .25 & .01 \\
Mountains & .20 & .00 \\
\hline Global L1 Distance & .95 & .17 \\
\hline
\end{tabular}

\section{Before and After Matching \\ Average Travelling Time}

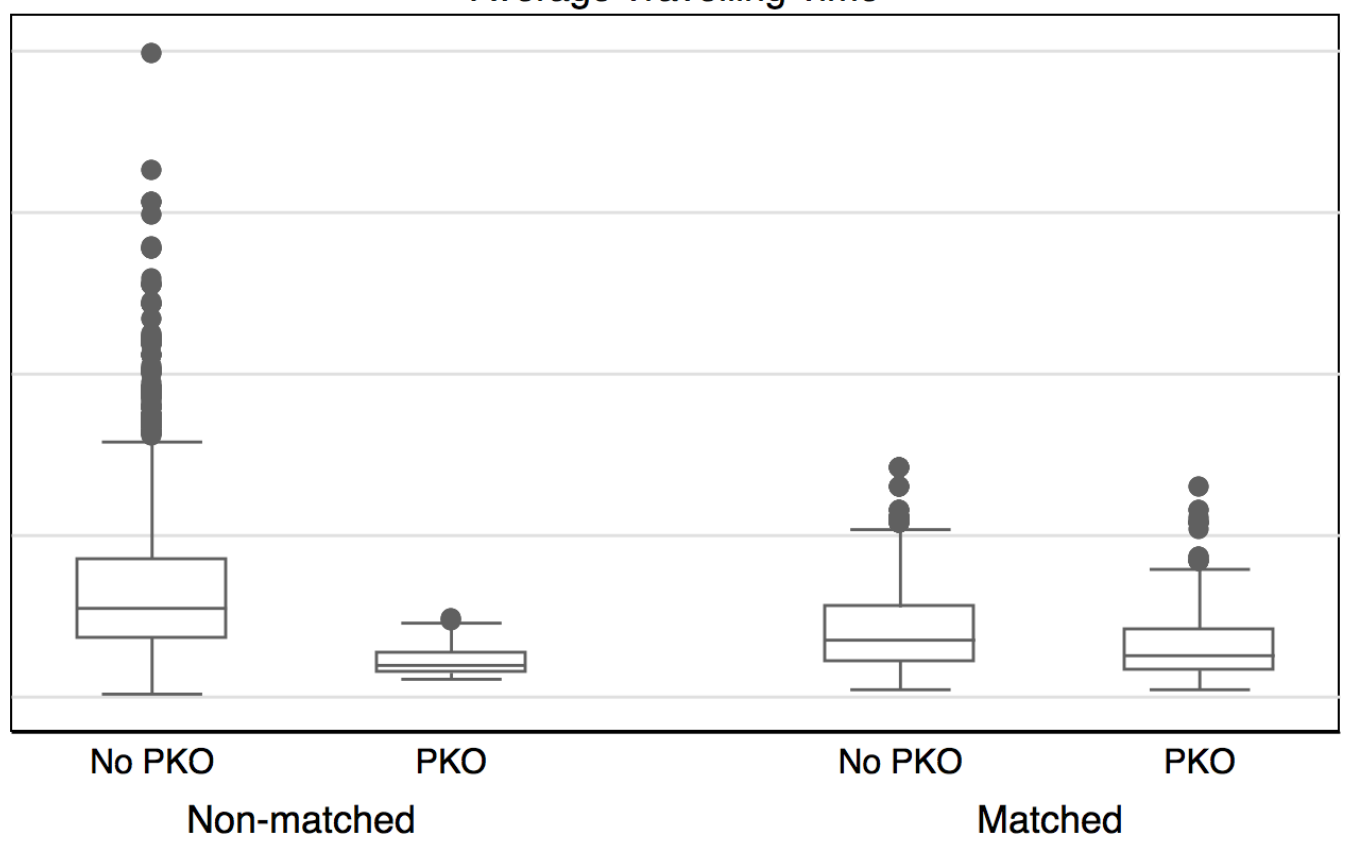




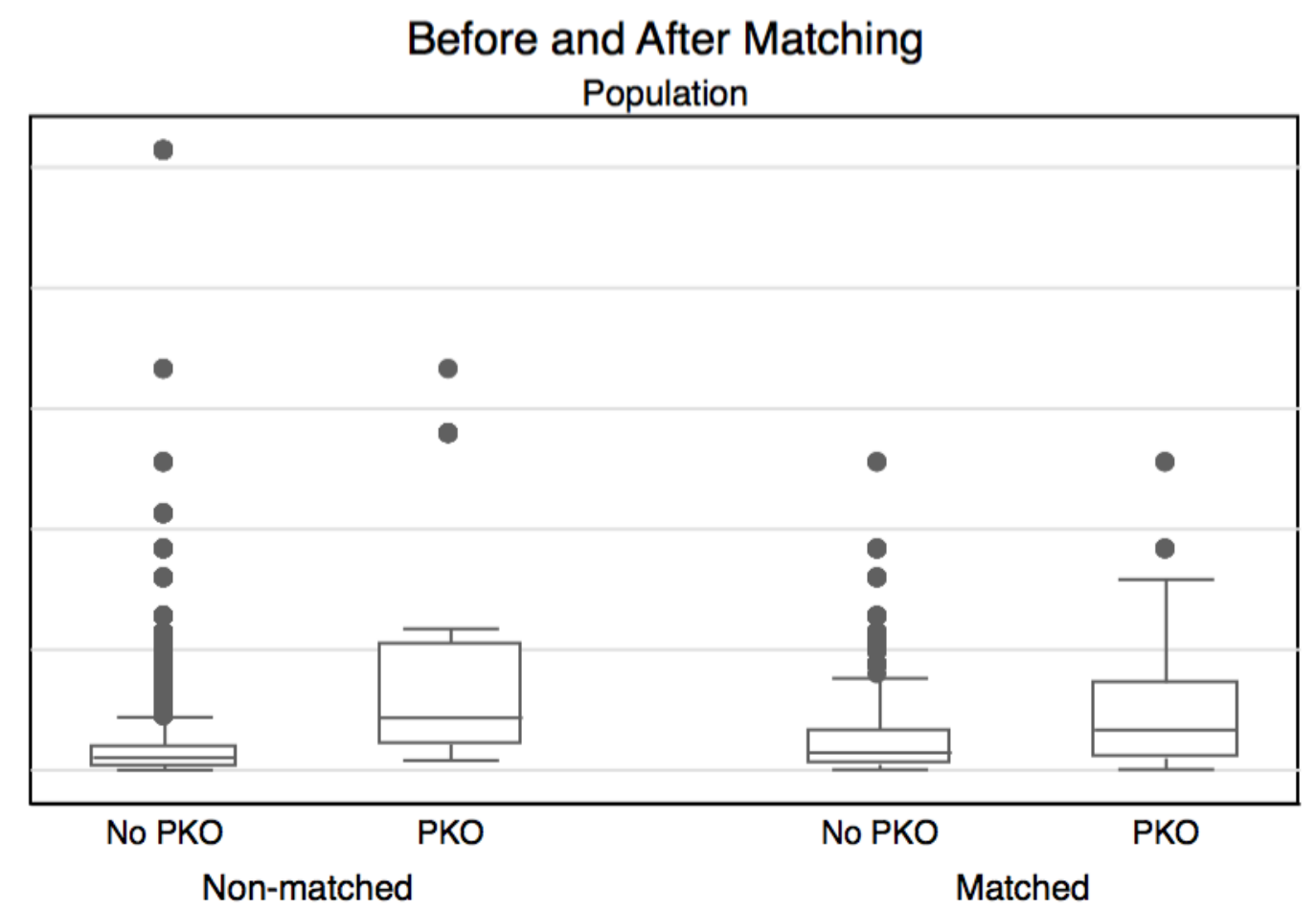

Figure 2: The Impact of CEM Matching on the Distribution of Population and Travelling Time.

Matching on observables cannot fully address possible selection bias, hence we also report the results of recursive bivariate probit since these models address possible selection on unobservables. ${ }^{51}$ In our empirical analysis, the bivariate probit model accounts for the endogenous choice of peacekeeper deployment locally. In line with Maddala, ${ }^{52}$ we specify a recursive bivariate probit of two equations with dichotomous outcomes. The outcome of the first regression is PKO presence in a grid, and the dependent variable of the second equation is local conflict. Both equations are estimated simultaneously taking into account the correlation in the equations' error processes. Finally, we use the interaction between supply

\footnotetext{
${ }^{51}$ Greene 2003, 715-716.

${ }^{52}$ Maddala 1983, 122.
} 
of peacekeepers in Africa and distance to the capital as an exogenous source of variation in the PKO deployment equation.

\section{Findings}

Table 2 reports the main results of PKO deployment on conflict applying Markov transition models on the matched sample. Model 1 reports the findings for the probability of onset of conflict in a grid-year, while Model 2 presents the effect on the probability that conflict continues for another year. In both models the key explanatory variable is $P K O$ presence. In Model 1, the coefficient of $P K O$ presence is negative but not statistically significant.

Contrary to Hypothesis 1, we do not find clear support that the presence of peacekeepers significantly reduces the probability of conflict onset locally. The coefficient for $P K O$ presence is negative and statistically significant in Model 2 and supports Hypothesis 3: the deployment of peacekeepers significantly decreases the risk of conflict duration in a particular grid. The impact of the deployment of peacekeepers is not only statistically significant but also relevant in substantive terms. If peacekeepers are deployed locally, the probability that conflicts last for another year in a particular grid decreases by $14 \%$. In contrast, $P K O$ presence only has a very small (2\%) marginal impact on probability of conflict onset, and the effect is not statistically significant. The control variables are consistent with the findings in previous studies on the subnational dynamics of conflict.

A possible concern is that matching techniques only take into account observables in determining non-random assignment of the treatment, in our case peacekeepers. Table 3 provides as alternative estimator an autorecursive bivariate probit that aims to take care of unobservable modelling of the correlation of the residuals of the two equations (local presence peacekeepers in the first equation and local conflict in the second). The results of the bivariate probit regression are in line with the previous analysis. PKO presence fails to 
significantly decrease the odds of conflict onset in a grid-year. Yet, PKO presence decreases the odds that an area with conflict in the previous period continues to experience conflict. The findings for PKO presence in Model 4 thus lend further support to Hypothesis 3: PKO deployment reduces the duration of conflict in a particular grid.

Ideally, the bivariate probit regression includes an exogenous source of variation in the first equation, but finding an exogenous source of variation with both temporal and subnational geographic variation is particularly challenging. Recently, scholars who study peacekeeping effectiveness analysing between-countries variation-instead of subnational variation like this article- -have provided some possible suggestions. Ijaz ${ }^{53}$ proposes the supply of peacekeepers and Vivalt ${ }^{54}$ the rotation within the UN Security Council as instruments for the non-random assignment of peacekeeping. However, these variables do not vary within countries, and therefore are not useful for our analysis.

To find exogenous variation in the first stage of the bivariate probit model, we use an interaction between two variables: one a temporal variant and the other a geographic variant. The use of an interaction that is exogenous whereas its main terms can be endogenous, has been proposed recently. ${ }^{55}$ In our analysis, the interaction needs to explain theoretically and empirically the variation of local UN deployment but not the local level of conflict. Accordingly, we use an interaction between supply of peacekeepers in Africa and distance to the capital. When there are more flows of peacekeepers in Africa, it is easier to have deployment in subnational areas, where we de-trend the variable to avoid historical temporal trends. The effect of this supply is subnationally conditional on the distance from the capital,

${ }^{53}$ Ijaz 2014.

${ }^{54}$ Vivalt 2015.

${ }^{55}$ First in Economics: Card \& Di Nardo 2000; Auer 2013. More recently in Political Science: Wucherpfennig, Hunziker and Cederman 2016; Esarey 2015. 
since it is harder to deploy far away from the capital. The interaction theoretically explains deployment at local level but not directly local conflict. We also find empirically that logit regressions with this interaction explain deployment but not local conflict. ${ }^{56}$ The first (deployment) equation of Model 5 (in Table 3) includes the interaction, but the variables are excluded for the second (conflict) equation. Notably, the effect of PKO presence on the probability of conflict duration is robust.

${ }^{56}$ See Table I in online appendix. 
Table 2: Peacekeeping Presence and the Onset and Duration of Local Conflict; Logit Regression on Matched Data

(1) (2)

Onset of Conflict Duration of Conflict

\begin{tabular}{|c|c|c|}
\hline PKO Presence & $\begin{array}{l}-0.662 \\
(0.603)\end{array}$ & $\begin{array}{c}-1.452 * * * \\
(0.262)\end{array}$ \\
\hline Distance to Borders & $\begin{array}{l}-0.003 \\
(0.002)\end{array}$ & $\begin{array}{c}0.007 * * * \\
(0.001)\end{array}$ \\
\hline Distance to Capital & $\begin{array}{c}-0.004 * * * \\
(0.001)\end{array}$ & $\begin{array}{c}0.001 * * * \\
(0.000)\end{array}$ \\
\hline Average Travelling & & \\
\hline Time & $\begin{array}{c}0.003 * * * \\
(0.001)\end{array}$ & $\begin{array}{c}0.003 * * * \\
(0.001)\end{array}$ \\
\hline Infant Mortality & $\begin{array}{c}0.031^{* *} \\
(0.015)\end{array}$ & $\begin{array}{c}0.098 * * * \\
(0.013)\end{array}$ \\
\hline Population & $\begin{array}{l}0.013 * \\
(0.006)\end{array}$ & $\begin{array}{c}0.001 \\
(0.003)\end{array}$ \\
\hline Mountains & $\begin{array}{c}4.475^{* * * *} \\
(1.070)\end{array}$ & $\begin{array}{c}0.995 * \\
(0.533)\end{array}$ \\
\hline Precipitation & $\begin{array}{c}-0.006^{* * *} \\
(0.001)\end{array}$ & $\begin{array}{c}-0.001 * * * \\
(0.000)\end{array}$ \\
\hline Peace years & $\begin{array}{c}12.996 * * * \\
(2.748)\end{array}$ & \\
\hline$(\text { Peace years })^{2}$ & $\begin{array}{c}-3.487 * * * \\
(0.838)\end{array}$ & \\
\hline$(\text { Peace years })^{3}$ & $\begin{array}{c}0.280 * * * \\
(0.077)\end{array}$ & \\
\hline Conflict years & & $\begin{array}{c}-4.017 * * * \\
(1.026)\end{array}$ \\
\hline$(\text { Conflict years })^{2}$ & & $\begin{array}{c}1.238 * * * \\
(0.326)\end{array}$ \\
\hline$(\text { Conflict years })^{3}$ & & $\begin{array}{c}-0.129 * * * \\
(0.030)\end{array}$ \\
\hline Constant & $\begin{array}{c}-11.148 * * * \\
(3.088)\end{array}$ & $\begin{array}{c}-8.662 * * * \\
(1.757)\end{array}$ \\
\hline Observations & 638 & 704 \\
\hline Log Likelihood & -66.62 & -211.4 \\
\hline$\chi^{2}$ & 180.0 & 309.0 \\
\hline Pseudo R2 & 0.575 & 0.422 \\
\hline $\mathrm{AIC}$ & 157.2 & 446.8 \\
\hline
\end{tabular}


Table 3: Peacekeeping Presence and the Onset and Duration of Local Conflict;

Recursive Bivariate Probit, Non-matched Data

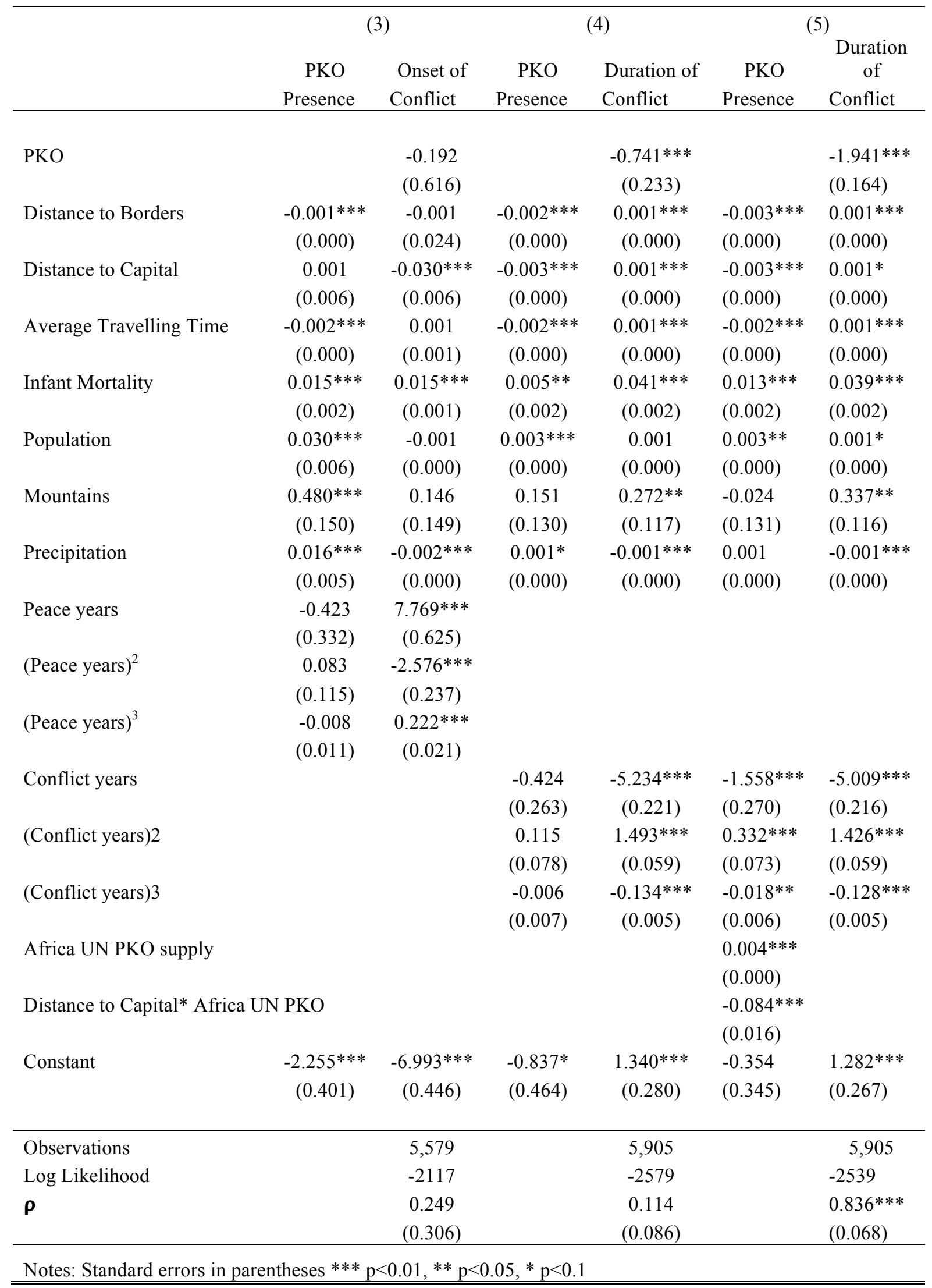


Table 4: Size of Peacekeeping Deployment and the Onset and Duration of Local Conflict; Logit Regression on Matched Data

\begin{tabular}{|c|c|c|}
\hline & $\begin{array}{c}(6) \\
\text { Onset }\end{array}$ & $\begin{array}{c}(7) \\
\text { Duration }\end{array}$ \\
\hline PKO size & $\begin{array}{c}-0.211^{*} \\
(0.111)\end{array}$ & $\begin{array}{c}-0.259 * * * \\
(0.041)\end{array}$ \\
\hline Distance to Borders & $\begin{array}{c}-0.003 \\
(0.002)\end{array}$ & $\begin{array}{c}0.006^{* * *} \\
(0.001)\end{array}$ \\
\hline Distance to Capital & $\begin{array}{c}-0.003 * * * \\
(0.001)\end{array}$ & $\begin{array}{c}0.001 * * * \\
(0.000)\end{array}$ \\
\hline Average Travelling & & \\
\hline Time & $\begin{array}{c}0.003 * * * \\
(0.001)\end{array}$ & $\begin{array}{c}0.003 * * * \\
(0.001)\end{array}$ \\
\hline Infant Mortality & $\begin{array}{c}0.033 * * \\
(0.015)\end{array}$ & $\begin{array}{c}0.095 * * * \\
(0.013)\end{array}$ \\
\hline Population & $\begin{array}{c}0.014 * * \\
(0.005)\end{array}$ & $\begin{array}{c}0.001 \\
(0.003)\end{array}$ \\
\hline Mountains & $\begin{array}{c}4.971 * * * \\
(1.147)\end{array}$ & $\begin{array}{c}0.797 \\
(0.538)\end{array}$ \\
\hline Precipitation & $\begin{array}{c}-0.006 * * * \\
(0.001)\end{array}$ & $\begin{array}{c}-0.001 * * * \\
(0.000)\end{array}$ \\
\hline Peace years & $\begin{array}{c}12.518 * * * \\
(2.782)\end{array}$ & \\
\hline$(\text { Peace years })^{2}$ & $\begin{array}{c}-3.369 * * * \\
(0.845)\end{array}$ & \\
\hline$(\text { Peace years })^{3}$ & $\begin{array}{c}0.273 * * * \\
(0.078)\end{array}$ & \\
\hline Conflict years & & $\begin{array}{c}-3.762 * * * \\
(1.042)\end{array}$ \\
\hline$(\text { Conflict years })^{2}$ & & $\begin{array}{c}1.191 * * * \\
(0.331)\end{array}$ \\
\hline$(\text { Conflict years })^{3}$ & & $\begin{array}{c}-0.126^{* * *} \\
(0.030)\end{array}$ \\
\hline Constant & $\begin{array}{c}-11.441 * * * \\
(3.170)\end{array}$ & $\begin{array}{c}-8.737 * * * \\
(1.763)\end{array}$ \\
\hline Observations & 638 & 704 \\
\hline Log Likelihood & -65.34 & -206.0 \\
\hline$\chi^{2}$ & 182.6 & 319.9 \\
\hline Pseudo R2 & 0.583 & 0.437 \\
\hline AIC & 154.6 & 435.9 \\
\hline
\end{tabular}


There is evidence that the size of the deployment matters as well. Table 4 reports the main results of the Markov transition models using the size of PKO deployment in a grid-year as main explanatory variable. The larger the size of the PKO deployment the lower is the risk of conflict in a grid-year. Models 6 and 7 respectively show that the size of the PKO has a statistically significant effect in reducing the probability of conflict onset as well as duration in any grid-year, which supports Hypotheses 2 and 4. The substantive impact of increasing the PKO deployment by one unit is to reduce the probability of conflict onset by about $0.7 \%$, while it reduces the probability of duration of conflict by about $2 \%$. A graphical presentation of the (simulated) effect of increasing the size of PKO deployment is, however, more insightful. Figure 3 shows the simulations on the probability of conflict onset based on the estimation of Model 6 (Table 4), when the size of the PKO deployment increases to up to 500 troops. Figure 3 suggests that the local presence of a relatively small number of peacekeepers (from no deployment to 50 troops) can decrease the probability of conflict onset from around $11 \%$ to $7 \%$, though within overlapping confidence intervals. The marginal impact of any further increase in the number of peacekeepers is negligible. However, the estimated effects are very uncertain as shown by the wide confidence intervals and the substantial effect in change of probability appears marginal; therefore, we remain uncertain on the local capacity of PKO to prevent onset of conflict, and consider the support for Hypothesis 3 as rather weak. However, supporting Hypothesis 4, the effect of the size of PKO deployment on the probability of the duration of conflict in a grid-year is more informative. Figure 4 shows that an increase in the number of peacekeepers (from no troops to 300 troops) reduces the probability that conflict continues into the next time period. Even a small deployment of 20 peacekeepers already reduces the probability that conflict continues in a particular location from $90 \%$ to $75 \%$. A more substantial deployment of about 500 peacekeepers reduces the probability that the conflict continues down to $48 \%$. However, 500 units appear to be a 
threshold because the marginal effect of adding further units seems negligible. To put these figures in context: the median value of peacekeepers size, where UN is deployed, is 562 units, the $25 \%$ percentile is 150 and the $75 \%$ percentile is 1703 .

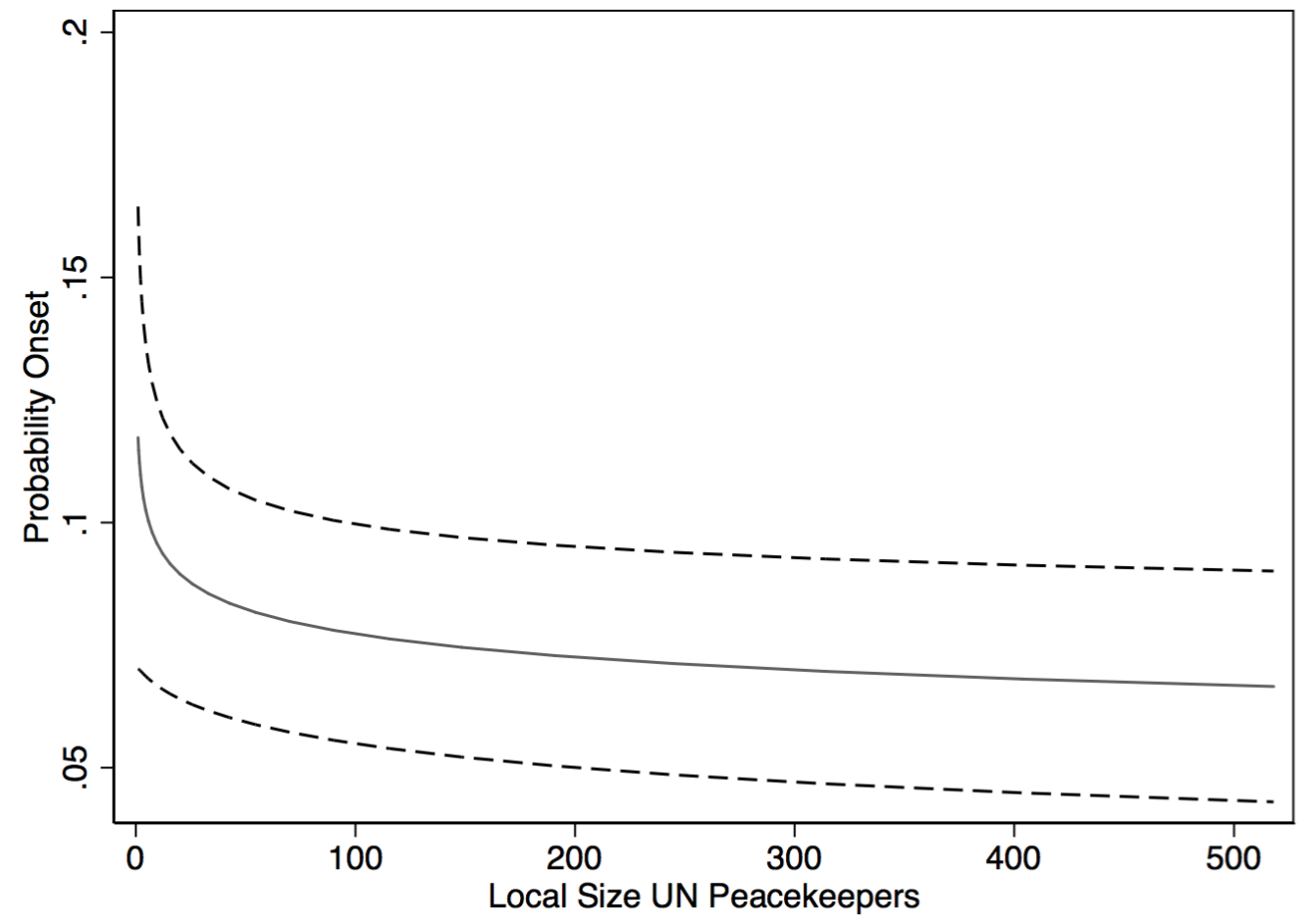

Figure 3: Probability of Local Conflict Onset as a Function of the Size of Peacekeeper Deployment. Simulations based on Model 6 (Table 4). 


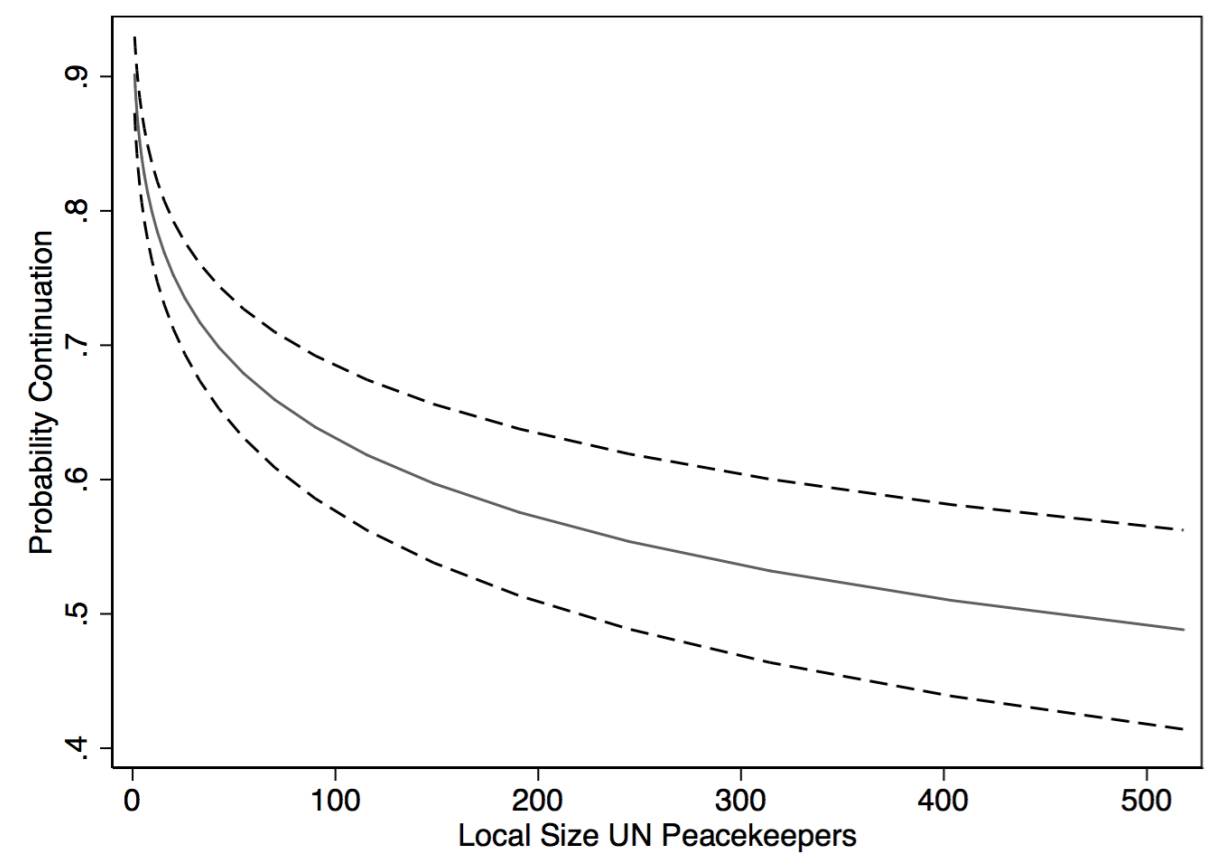

Figure 4: Probability of Duration of Local Conflict as a Function of the Size of Peacekeeper Deployment. Simulations based on Model 7 (Table 4).

As a first robustness test, we have replicated the models using the UCDP-GED data. ${ }^{57}$ The results remain the same for the $P K O$ presence. $P K O$ size is no longer statistically significant for the conflict onset, while $P K O$ presence and size both significantly reduce the probability that conflict continues in a grid-year. We present grid-year instead for the month-event analyses for two reasons. First, the Conflict Site Dataset is compiled on year grid and aims to geographically identify areas where a conflict has reached levels of civil war. The UCDPGED reports conflict events that do not necessarily identify a civil war. Second, nearly all independent variables only have yearly variation and using monthly observations would artificially inflate the sample.

${ }^{57}$ Sundberg and Melander 2013. 
As additional robustness tests we ran models with the same specifications as in Tables 2 and 4 but added spatial lags for peacekeepers deployment. Higher values on the spatial lags mean that peacekeepers are deployed more proximate to a particular area. The spatial lags for PKO size are weighted on the size of the deployment. Figure 5 visually represents the effects of the spatial lags. ${ }^{58}$ The upper two graphs suggest possible diffusion (if PKO deployment is closer there appears to be a higher probability of conflict onset), but the confidence intervals indicate that the results are not statistically significant. Further, the bottom two graphs suggest that closer deployment of peacekeepers decreases the probability of local conflict duration. Overall, we conclude that any evidence of the diffusion of conflict because of peacekeeping is weak: the evidence that peacekeeping diffuses the onset of conflict is positive but insignificant, while the evidence that peacekeepers via diffusion prolong conflict is negative and significant. Again, adding the spatial lags of peacekeeping deployment to our main specifications does not influence the substantial effects of our main explanatory variables. Finally, even controlling for spatial lags of conflict does not affect our main findings. $^{59}$

\footnotetext{
${ }^{58}$ We use the one-year temporal lag of the spatial lag to operationalize diffusion and to avoid simultaneity bias (see Beck et al. 2006), full models in appendix Table F.

${ }^{59}$ See Table G in the online appendix.
} 

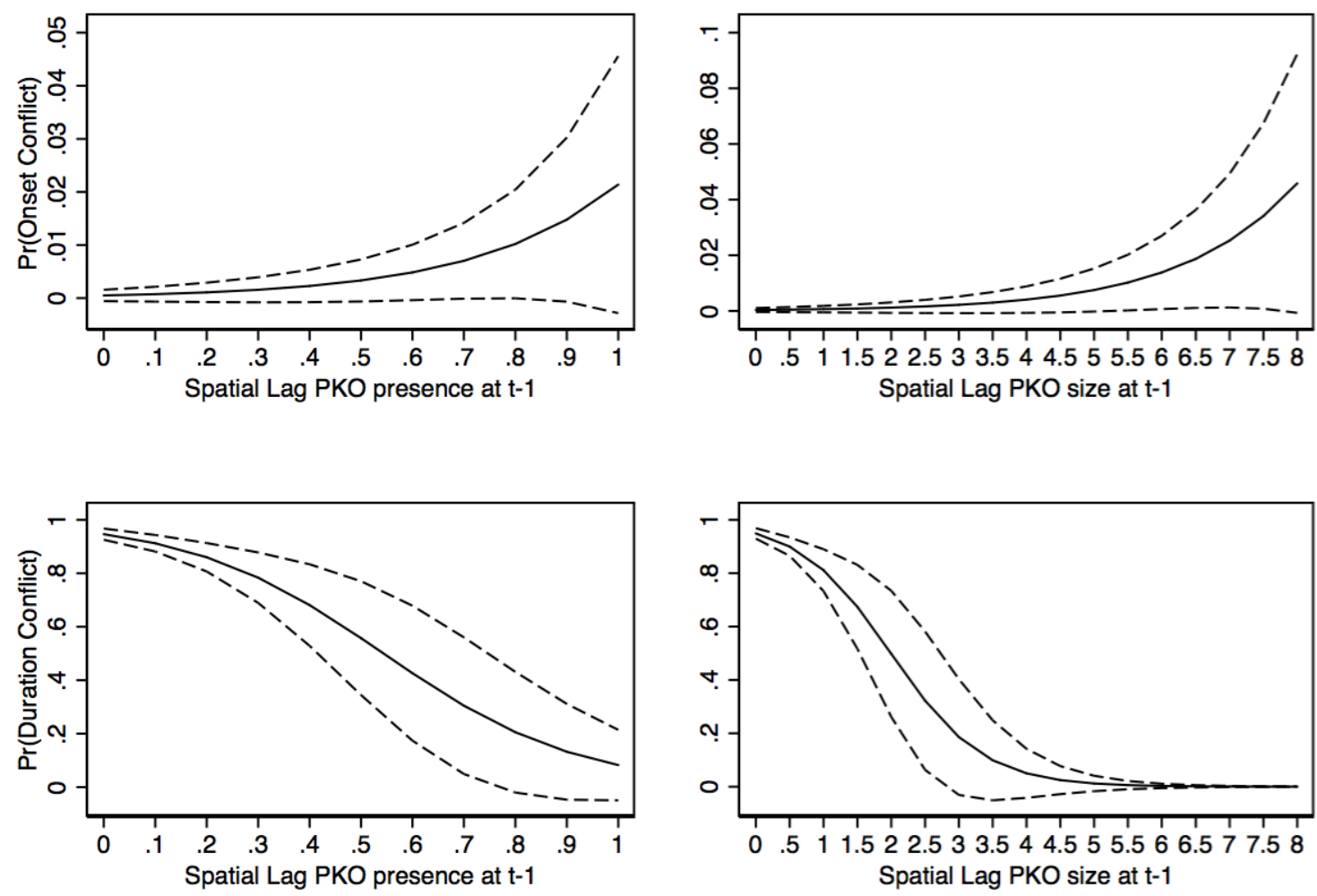

Figure 5: Spatial Effects of Peacekeepers Local Deployment on Probability Conflict Onset and Duration.

\section{Conclusions}

The local determinants and impact of peacekeepers have attracted relatively little attention and the findings are often contradictory. A reason could be that common understandings of 'local' conflate the possible strategic importance of certain localities with endogenous or local conflict dynamics. Autesserre ${ }^{60}$ makes a strong case that the failure of peacekeepers to address local conflict dynamics contributed to the difficulties of the UN to build a sustainable peace in the DRC. Hultman, Kathman and Shannon and Fjelde, Hultman and Nilsson ${ }^{61}$

\footnotetext{
${ }^{60}$ Autesserre 2010.

${ }^{61}$ Hultman et al. 2013; 2014; Fjelde et al. 2015.
} 
demonstrate that peacekeeping helps to protect civilian lives. Here, we provide evidence that peacekeepers also reduce violent confrontations between belligerents. Robust peacekeepers fill power vacuums that emerge post-conflict. While the deployment of peacekeepers often follows a centrally reached agreement between government and rebel leaders, peacekeepers have increasingly had responsibilities to keep the peace locally. Peacekeepers have to deter and contain conflict 'hotspots', commit parties to the peace process, provide information on local developments, and force local actors to stop fighting.

Effective peacekeeping averts the onset of conflict in a particular locality and halts conflict if it emerges anyway. To assess the actual effectiveness of peacekeeping, it is necessary to account for possible non-random assignment of the treatment, namely subnational PKO deployment. Our analysis proceeds accordingly with the key finding that UN peacekeepers contain conflict locally. There is some, however inconclusive, evidence that UN peacekeepers may also deter local conflict altogether. UN peacekeepers significantly reduce the probability of local conflict continuing for another year. While the mere presence of peacekeepers already matters, the impact is stronger if a larger number of peacekeepers are deployed. These findings are robust using two different approaches to deal with possible nonrandom assignment of subnational peacekeeping.

The weak effects of peacekeeping on deterring the onset of conflict seem in line with the comparatively modest size of peacekeeping deployment, especially given the amount of territory that the peacekeepers are expected to control. PKOs simply often lack the capacity to effectively patrol their entire area of operations leaving opportunities for violence by spoilers. These findings suggest that peacekeepers are unable to deter opportunistic actions by elites with either a strong national or local powerbase. Peacekeepers are, however, willing and able to respond to local conflict whenever and wherever it emerges. We find strong support for the idea that a robust deployment of peacekeeping forces in a particular locality 
can compensate for the lack of control of central authorities; in other words, places with a power vacuum. The presence of peacekeepers — even with modest size—also allows for mediation of local grievances supporting the relevance of local conflict dynamics. Although peacekeepers seem unable to stop local conflict completely, they are able to prevent it from continuing unchecked. Instead of 'winning' the peace locally, our findings suggest that peacekeepers are able to restore the peace locally with enforcement and reassurance being the two main conflict resolution mechanisms.

Notably, UN PKO missions rarely reach the deployment levels of a military intervention. For example, in 2013 the deployment of ISAF forces to Afghanistan peaked at approximately 100,000 military personnel. In contrast, the largest UN mission to the DRC deployed about 22,000 troops in 2013. The military containment of M23 in DRC in 2013 highlights that UN PKOs can successfully use targeted military force under an appropriate mandate. The UN Force Intervention Brigade under the United Nations Organization Stabilization Mission in the Democratic Republic of the Congo (MONUSCO) deployed approximately 3,000 peacekeepers in North Kivu and carried offensive operations against M23, forcing the rebel group to eventually end hostilities. Thus, effective UN peacekeeping combines the ability to monitor transgressions with targeted use of military force.

We recognize the limitations of our study. First, our study covers only major UN missions in Africa after the Cold War. Still it provides a new and innovative empirical contribution on the local effects of peacekeepers. In our opinion, the tradeoff between limited scope and more detailed information on conflict resolution processes seems more than acceptable. Moreover, civil wars and peacekeeping missions in the African continent represent an important share at global level. Second, we use a minimal conceptualization of local peace, operationalized as absence of local conflict, and have left the possible effect on positive peace to future research. To some extent, this reconciles our findings with the more 
negative evaluation of Autesserre ${ }^{62}$ who considers the impact of wider UN involvement - and thus not only the Blue Helmets — on peace building or positive peace. Third, we lack information about the precise actions and policies implemented locally by UN peacekeepers. Arguably, the latter are crucial for winning the peace locally. Regardless, in our opinion, demonstrating that peacekeepers make a difference to local conflict is important. Limiting post-conflict violence is crucial to maintain confidence in the peace process and to allow 'peace' to take hold. As shown by events in the DRC, failing to control local conflict poses clear challenges to the overall peace process. Local deployment of UN peacekeepers can shorten conflict and, therefore, save lives.

${ }^{62}$ Autesserre 2010. 


\section{References}

Auer, Raphael. 2013. "Geography, Institutions, and the Making of Comparative Development." Journal of Economic Growth 18(2): 179-215.

Autesserre, Séverine. 2010. The Trouble with the Congo. Cambridge: Cambridge University Press.

Beck, Nathaniel, Kristian S. Gleditsch and Kyle Beardsley. 2006. "Space is more than Geography: Using Spatial Econometrics in the Study of Political Economy." International Studies Quarterly 50(1): 27-44.

Beck, Nathaniel, Jonathan N. Katz and Richard Tucker. 1998. "Taking Time Seriously: Time-Series-Cross-Section Analysis with a Binary Dependent Variable." American Journal of Political Science 42(4): 1260-1288.

Boulding, Kenneth.1962. Conflict and Defense: A General Theory. San Francisco: Harper \& Bros.

Braithwaite, Alex. 2005. "Location, Location, Location...Identifying Conflict Hot Spots." International Interactions 31(4): 251-272.

Buhaug, Halvard. 2010. "Dude, Where's My Conflict? LSG, Relative Strength, and the Location of Civil War." Conflict Management and Peace Science 27(2): 107-128.

Buhaug, Halvard and Jan Ketil Rød. 2006. "Local Determinants of African Civil Wars, 1970-2001.” Political Geography 25(3): 315-335.

Card, David, and John DiNardo. 2000. "Do Immigrant Inflows Lead To Native Outflows?" American Economic Review 90(2): 360-367.

Carter, David B., and Curtis S. Signorino. 2010. "Back to the future: Modeling time dependence in binary data." Political Analysis 18(3): 271-292.

Costalli, Stefano.2013. "Does Peacekeeping Work? A Disaggregated Analysis of Deployment and Violence Reduction in the Bosnian War." British Journal of Political Science 44(2): 357-380.

Dittrich Hallberg, Johan. 2012. "PRIO Conflict Site 1989-2008: A geo-referenced dataset on armed conflict." Conflict Management and Peace Science 29(2): 219-232.

Esarey, Justin. 2015. Using Interaction Terms as Instrumental Variables for Causal Identification: Does Corruption Harm Development. Working Paper Rice University Houston, http://jee3.web.rice.edu/instrument-interact.pdf [accessed 1 February 2016].

Fjelde, Hanne, Lisa Hultman, and Desirée Nilsson. 2015. The Micro-foundations of civil protection. Credible deterrence in peacekeeping operations. Working Paper University of Uppsala. 
Fortna, Virginia P. 2008. Does Peacekeeping Work? Shaping Belligerents' Choices after Civil War. Princeton, N.J.: Princeton University Press.

Gilligan, Michael J. and Ernest J. Sergenti. 2008. "Do UN Interventions Cause Peace? Using Matching to Improve Causal Inference.” Quarterly Journal of Political Science 3(2): 89-122.

Greene, William H. 2003. Econometric Analysis. Prentice Hall: Pearson.

Hegre, Håvard, Lisa Hultman and Håvard Mokleiv Nygård. 2011. "Simulating the Effect of Peacekeeping Operations 2010-2035," in Sun-Ki Chai, John Salerno and Patricia L. Mabry, eds., Advances in Social Computing. Lecture Notes in Computer Science. Heidelberg: Springer, pp. 325-332.

Hultman, Lisa, Jacob Kathman, and Megan Shannon. 2013. "United Nations Peacekeeping and Civilian Protection in Civil War." American Journal of Political Science 57(4): 875-891.

Hultman, Lisa, Jacob Kathman, and Megan Shannon. 2014. "Beyond Keeping Peace: United Nations Effectiveness in the Midst of Fighting." American Political Science Review 108(4): 737-753.

Ijaz, Syeda ShahBano, 2014. The Selection Problem in Peacekeeping Missions: Developing an Instrumental Variable. Working Paper NYU New York.

Iacus, Stefano, Gary King, and Giuseppe Porro. 2011. "Causal Inference Without Balance Checking: Coarsened Exact Matching." Political Analysis 20(1): 1-24.

Imbenes, Guido. 2014. "Matching Methods in Practice: Three Examples." National Bureau of Economic Research Working Paper Series.

Kalyvas, Stathis N. 2006. The Logic of Violence in Civil War. Cambridge: Cambridge University Press.

Kydd, Andrew, and Barbara Walter. 2002. "Sabotaging the Peace: The Politics of Extremist Violence." International Organization 56(2): 263-296.

Lindley, Dan. 2007. Promoting Peace with Information: Transparency as a Tool of Security Regimes. Princeton N.J.: Princeton University Press.

Maddala, Gangadharrao S. 1983. Limited-Dependent and Qualitative Variables in Econometrics. Cambridge: Cambridge University Press.

Melander, Erik. 2009. "Selected to Go Where Murderers Lurk? The Preventive Effect of Peacekeeping on Mass Killings of Civilians." Conflict Management and Peace Science 26: 389-406.

Mitchell, Neil J. 2009. Agents of atrocity: Leaders, followers, and the violation of human rights in civil war. London: Macmillan. 
Mueller, John. 2003. "Policing the Remnants of War." Journal of Peace Research 40(5): 507-518.

Nelson, A. 2008. "Travel time to major cities: A global map of Accessibility." Global Environment Monitoring Unit - Joint Research Centre of the European Commission, Ispra Italy. Available at http://gem.jrc.ec.europa.eu/.

Nilsson, Desirée. 2008. "Partial Peace: Rebel Groups Inside and Outside of Civil War Settlements." Journal of Peace Research 45(4): 479-495.

Olonisakin, 'Funmi. 2008. Peacekeeping in Sierra Leone: The Story of UNAMSIL. Boulder, $\mathrm{CO}$ and London: Lynne Reinner Publishers.

Pons-Vignon, Nicolas, and Henri-Bernard Solignac-Lecomte. 2004. "Land, Violent Conflict and Development." OECD Development Centre Working Paper No 233.

Pouligny, Beatrice. 2006. Peace Operations Seen From Below. Bloomfield, CT: Kumarian Press.

Powell, Robert. 2004. "Bargaining and learning while fighting." American Journal of Political Science 48(2): 344-361.

Prunier, Gérard. 2008. Africa's World War. Congo, the Rwandan Genocide, and the Making of a Continental Catastrophe. Cambridge, Mass.: Oxford University Press.

Rotberg, Robert I. 2002. When States Fail. Princeton, N.J.: Princeton University Press.

Sambanis, Nicholas, and Michael Doyle. 2007. "No Easy Choices: Estimating the Effects of the United Nations Peacekeeping.” International Studies Quarterly 51:217-226.

Sundberg, Ralph, and Erik Melander. 2013. "Introducing the UCDP georeferenced event dataset." Journal of Peace Research 50(4): 523-532.

Tollefsen, A., Forø, H. Strand and H. Buhaug. 2012. "PRIO-GRID: A unified spatial data structure." Journal of Peace Research 49(2): 363-374.

UN DPKO. 2008. Capstone Doctrine: United Nations Peacekeeping Operations: Principles and Guidelines. New York: United Nations

(http://pbpu.unlb.org/pbps/library/capstone_doctrine_eNg.pdf).

Vivalt, Eva. 2015. Peacekeepers Help, Governments Hinder”. Working Paper NYU New York.

Wall, James Jr. and Daniel Druckman. 2003. “Mediation in Peacekeeping Missions.” Journal of Conflict Resolution 47:5 (2003), 693-705.

Wooldridge, Jeffrey. 2009. Econometric Analysis of Cross Section and Panel Data, Cambridge, MA: MIT Press. 
Wucherpfennig, Julian, Philipp Hunziker and Lars-Erik Cederman, 2016. "Who Inherits the State? Colonial Rule and Post-Colonial Conflict." American Journal of Political Science. DOI: 10.1111/ajps.12236. 